\title{
Corrigendum
}

\section{Corrigendum \#2 to "Expanding Thermal Plasma Chemical Vapour Deposition of ZnO:Al Layers for CIGS Solar Cells"}

\author{
K. Sharma $\mathbb{D}^{1}{ }^{1}$ B. L. Williams $\mathbb{D}^{1},{ }^{1}$ A. Mittal, ${ }^{1}$ H. C. M. Knoops $\mathbb{D}^{1},{ }^{1}$ B. J. Kniknie, ${ }^{2,3}$ \\ N. J. Bakker, ${ }^{3,4}$ W. M. M. Kessels $\mathbb{D}^{1,3}$ R. E. I. Schropp, ${ }^{1,3,4}$ and M. Creatore $\mathbb{i}^{1,3}$ \\ ${ }^{1}$ Department of Applied Physics, Eindhoven University of Technology, P.O. Box 513, 5600 MB Eindhoven, Netherlands \\ ${ }^{2}$ TNO, P.O. Box 6235, 5600 HE Eindhoven, Netherlands \\ ${ }^{3}$ Solliance, High Tech Campus 21, 5656 AE Eindhoven, Netherlands \\ ${ }^{4}$ ECN, High Tech Campus 21, 5656 AE Eindhoven, Netherlands
}

Correspondence should be addressed to K. Sharma; k.sharma@tue.nl

Received 3 June 2020; Accepted 22 June 2020; Published 12 September 2020

Copyright (c) 2020 K. Sharma et al. This is an open access article distributed under the Creative Commons Attribution License, which permits unrestricted use, distribution, and reproduction in any medium, provided the original work is properly cited.

In the article titled "Expanding Thermal Plasma Chemical Vapour Deposition of ZnO:Al Layers for CIGS Solar Cells" [1], there was an error in the references list, as reference number 4 cited a wrong author's name (M. Jean) instead of Jonas Lähnemann, who is the actual author of that article [2].

\section{References}

[1] K. Sharma, B. L. Williams, A. Mittal et al., "Expanding thermal plasma chemical vapour deposition of $\mathrm{ZnO}$ :Al layers for CIGS solar cells," International Journal of Photoenergy, vol. 2014, Article ID 253140, 9 pages, 2014.

[2] J. Lähnemann, Spectrally resolved current losses in $\mathrm{Cu}(\mathrm{In}, \mathrm{Ga}) \mathrm{Se}_{2}$ thin-film solar cells, Freie Universität Berlin, Berlin, Germany, 2008. 